\title{
Effect of Motivation, Work Environment and Workload on Employee Performance at PT. Benua Penta Global Medan
}

\author{
Nurmaidah Ginting ${ }^{1}$, Putra Nagara $^{2}$, Selly $^{3}$, Ricky Yuwanto ${ }^{4}$, Diana Mariana ${ }^{5}$ \\ 1,2,3,4,5Universitas Prima Indonesia, Indonesia. \\ Corresponding Author: Nurmaidah Ginting
}

\begin{abstract}
This study is to determine and analyze the effect of motivation, work environment and workload on employee performance at PT. Benua Penta Global Medan. The research approach here is based on a quantitative approach. Sampling techniques are generally carried out randomly. The population used is employees as many as 137 people and the sample of this study amounted to 102 people obtained from the slovin formula. This research model uses multiple linear regression analysis. The results showed that motivation and workload partially had a significant effect on employee performance and work environment partially had no significant effect on employee performance. Simultaneously, motivation, work environment and workload have a significant effect on employee performance. The coefficient of determination seen from the adjusted $\mathrm{R}$ square is 0.283 which means that it implies that the effect of motivation, work environment and workload on employee performance is $28.3 \%$ and the remaining $71.7 \%$ is the influence of other independent variables not examined in this study such as competence, work stress, etc.
\end{abstract}

Keywords: Motivation, Work Environment, Workload, Employee Performance

\section{INTRODUCTION}

The development of the culinary world is very rapid at this time, where companies engaged in the culinary field are increasing rapidly. The amount of interest from consumers and also the high lifestyle of today's people makes the culinary field one of the businesses that many entrepreneurs are looking at. Likewise with PT. Benua Penta Global Medan, where this company is engaged in the Food and Beverage sector, which has been established since 2011, already has several outlets and also some food ingredients for distribution. However, in 2019 the company's sales decreased where the company got a very small year-end profit. The company's declining sales were due to the declining performance of employees.

Employee performance is decreasing where employees often do not reach the company's sales targets. The decline in employee performance at PT. Benua Penta Global Medan is caused by several things, one of which is employee motivation. Work motivation of employees at PT. Benua Penta Global Medan is very low. This can be seen from the lack of interest of employees in providing the best service for customers, besides that employees are also less enthusiastic in doing their jobs so that the performance of employees decreases.

In addition, the work environment at PT. Benua Penta Global Medan also affects employee performance where employees feel that the workplace provided by the company is not comfortable so that employees become less enthusiastic about working. In addition, coworkers or partners from work often experience misunderstandings in doing their daily work, causing employees to become less 
Nurmaidah Ginting et.al. Effect of motivation, work environment and workload on employee performance at PT. Benua Penta Global Medan.

cooperative in their work, resulting in poorer performance.

Workload at PT. Benua Penta Global Medan perceived by employees is also relatively high where employees are required to be able to do all the work in restaurant operations. In addition, employees also often get overtime schedules due to a lack of manpower, which makes employees have to be extra at work. The work given to employees is also considered too much which causes employees to feel increasingly burdened at work. With the high workload felt by employees, employees become increasingly lazy to work and if left further, employee performance will continue to decline.

This study is to determine and analyze the effect of motivation, work environment, and workload on employee performance at PT. Benua Penta Global Medan.

\section{LITERATURE REVIEW Motivation}

According to Bangun (2012:312), "motivation means a condition that encourages or causes someone to do an activity, which takes place consciously. According to Burhan (2014:131), motivation indicators are as follows: motives, expectations and incentives.

\section{Work Environment}

According to Supomo (2018:18), states that the environment is a pattern of all external conditions or factors that influence or lead to opportunities or threats to the company. According to Afandi (2018:71), the dimensions and indicators of the work environment are as follows: workplace lighting, color schemes, decorations and air temperature.

\section{Workload}

According to Hasibuan (2016:235), workload is a process to determine the number of working hours people use or need to complete a job within a certain time.
According to Koesomowidjojo (2017:24-33) in the world of work, there are several indicators to determine how much workload employees have to carry. These indicators include: working conditions, use of working time and targets to be achieved.

\section{Employee Performance}

According to Moeheriono (2012:95), the notion of performance or performance is a description of the level of achievement of the implementation of a program of activities or policies in realizing the goals, objectives, vision and mission of the organization as outlined through the strategic planning of an organization. According to Edison et al. (2016:195), performance indicators consist of four components, namely target, quality, time and compliance.

\section{RESEARCH METHOD}

The research approach here is based on a quantitative approach. Quantitative approach is an approach that in research proposals, processes, hypotheses, goes to the field, analyzes data and concludes data until the writing uses aspects of measurement, calculation, formulas and certainty of numerical data (Pandiangan et al., 2021). The quantitative approach is a research method based on the philosophy of positivism, used to examine a particular population or sample (Pandiangan, 2015).

Sampling techniques are generally carried out randomly. Simple random sampling is used as a sampling technique for this study and is also a technique used in drawing samples in this study (Pandiangan et al., 2018). The population used is employees as many as 137 people and the sample of this study amounted to 102 people obtained from the slovin formula.

Library research of reference sources is a form of research that uses library facilities by examining theoretical discussions from various books, articles, and scientific works related to writing (Pandiangan, 2018). 
Nurmaidah Ginting et.al. Effect of motivation, work environment and workload on employee performance at PT. Benua Penta Global Medan.

This research model uses multiple linear regression analysis. The research used multiple linear regression methods with ordinary least square (OLS) to find out how far the influence of independent variables on dependent variable (Tobing et al., 2018).

\section{RESULT}

\section{Hypothesis Testing (t Test)}

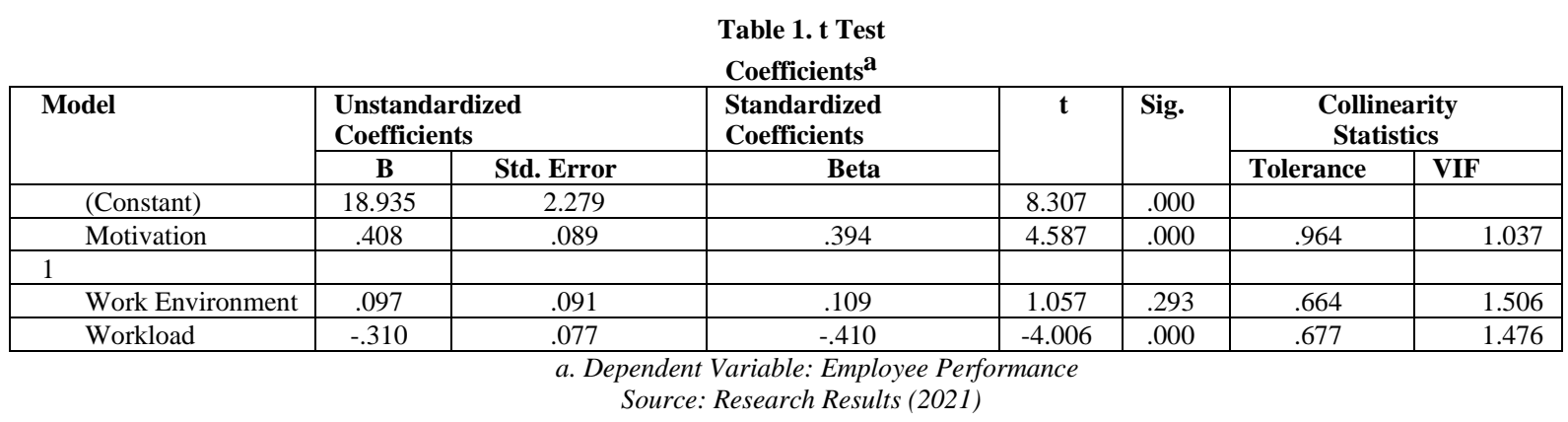

The results showed that motivation and workload partially had a significant effect on employee performance and work environment partially had no significant effect on employee performance.

\section{Hypothesis Testing (F Test)}

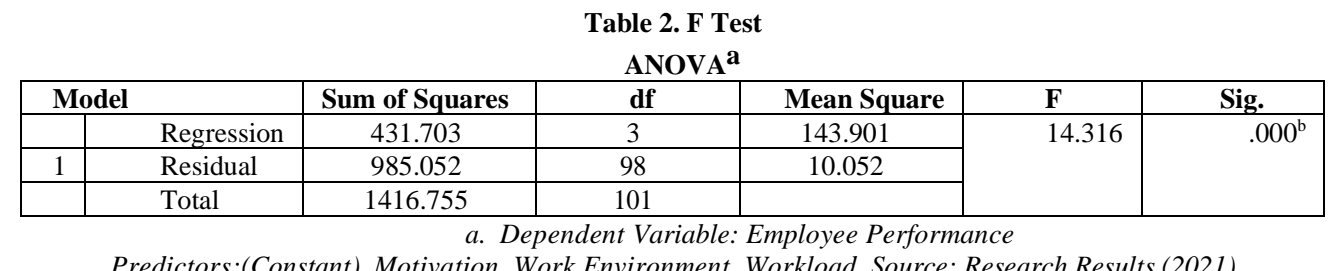

Simultaneously, motivation, work environment, and workload have a significant effect on employee performance.

\section{Coefficient of Determination (R2 Test)}

\begin{tabular}{|c|c|c|c|c|}
\hline \multicolumn{5}{|c|}{$\begin{array}{l}\text { Table 3. R2 Test } \\
\text { Model Summaryb }\end{array}$} \\
\hline Model & $\mathbf{R}$ & R Square & Adjusted R Square & Std. Error of the Estimate \\
\hline 1 & $.552^{\mathrm{a}}$ & .305 & .283 & 3.17042 \\
\hline
\end{tabular}

The coefficient of determination seen from the adjusted $\mathrm{R}$ square is 0.283 which means that it implies that the effect of motivation, work environment, and workload on employee performance is $28.3 \%$ and the remaining $71.7 \%$ is the influence of other independent variables not examined in this study such as competence, work stress, etc.

\section{CONCLUSION AND SUGGESTION}

The results showed that motivation and workload partially had a significant effect on employee performance and work environment partially had no significant effect on employee performance. Simultaneously, motivation, work environment, and workload have a significant effect on employee performance. The coefficient of determination seen from the adjusted $\mathrm{R}$ square is 0.283 which means that it implies that the effect of motivation, 
Nurmaidah Ginting et.al. Effect of motivation, work environment and workload on employee performance at PT. Benua Penta Global Medan.

work environment, and workload on employee performance is $28.3 \%$ and the remaining $71.7 \%$ is the influence of other independent variables not examined in this study such as competence, work stress, etc.

From the results above, the suggestions from the researchers are:

1. For researchers, the results obtained can provide more knowledge to researchers about the field of human resource management.

2. For PT. Benua Penta Global Medan should pay more attention to motivation, work environment and workload, so that employees are expected to work optimally and improve their performance.

3. For universities, the results of this research can be used as material for library studies, learning and adding insight into scientific research at Universitas Prima Indonesia.

4. For further researchers, to examine outside of the research conducted by researchers on employee performance, such as: job satisfaction and job characteristics.

\section{Acknowledgement: None}

\section{Conflict of Interest: None}

\section{Source of Funding: None}

\section{REFERENCES}

1. Afandi, Pandi. (2018). Manajemen Sumber Daya Manusia: Teori, Konsep dan Indikator. Riau: Zanafa Publishing.

2. Bangun, Wilson. (2012). Manajemen Sumber Daya Manusia. Jakarta: Erlangga.

3. Burhan. (2014). Penelitian Kualitatif. Jakarta: Kencana Prenada Media.

4. Edison, Anwar, \& Komariyah. (2016). Manajemen umber Daya Manusia. Bandung: Alfabeta

5. Hasibuan, H. Malayu. (2016). Manajemen umber Daya Manusia. Bandung: PT Remaja Rosdakarya.
6. Koesomowidjojo, Suci. (2017). Panduan Praktis Menyusun Analisis Beban Kerja. Jakarta: Raih Asa Sukses.

7. Moeheriono. (2012). Pengukuran Kinerja Berbasis Kompetensi. Jakarta: Raja Grafindo Persada.

8. Pandiangan, Saut Maruli Tua. (2015). Analisis Lama Mencari Kerja Bagi Tenaga Kerja Terdidik di Kota Medan. Skripsi. Medan: Fakultas Ekonomi dan Bisnis, Program Studi Ekonomi Pembangunan, Universitas Sumatera Utara.

https://www.academia.edu/52494724/A nalisis_Lama_Mencari_Kerja_Bagi_Ten aga_Kerja_Terdidik_di_Kota_Medan.

9. Pandiangan, Saut Maruli Tua. (2018). Analisis Faktor-faktor yang Mempengaruhi Penawaran Tenaga Kerja Lanjut Usia di Kota Medan. Tesis. Medan: Fakultas Ekonomi dan Bisnis, Program Studi Ilmu Ekonomi, Universitas Sumatera Utara. http://repositori.usu.ac.id/bitstream/hand le/123456789/10033/167018013.pdf?se quence $=1 \&$ isAllowed $=\mathrm{y}$.

10. Pandiangan, Saut Maruli Tua, Rujiman, Rahmanta, Tanjung, Indra I., Darus, Muhammad Dhio, \& Ismawan, Agus. (2018). An Analysis on the Factors which Influence Offering the Elderly as Workers in Medan. IOSR Journal of Humanities and Social Science (IOSRJHSS), 23(10), 76-79. DOI: 10.9790/0837-2310087679.

11. Pandiangan, Saut Maruli Tua, Resmawa, Ira Ningrum, Simanjuntak, Owen De Pinto, Sitompul, Pretty Naomi, \& Jefri, Riny. (2021). Effect of E-Satisfaction on Repurchase Intention in Shopee User Students. Budapest International Research and Critics Institute-Journal, 4(4), 7785-7791. DOI: https://doi.org/10.33258/birci.v4i4.2697.

12. Supomo. (2018). Manajemen Personalia. Bandung: Yrama Widya.

13. Tobing, Murniati, Afifuddin, Sya'ad, Rahmanta, Huber, Sandra Rouli, Pandiangan, Saut Maruli Tua, \& Muda, Iskandar. (2018). An Analysis on the 
Nurmaidah Ginting et.al. Effect of motivation, work environment and workload on employee performance at PT. Benua Penta Global Medan.

Factors Which Influence the Earnings of Micro and Small Business: Case at Blacksmith Metal Industry. Academic Journal of Economic Studies, 5(1), 1723.

https://www.ceeol.com/search/articledetail?id=754945.
How to cite this article: Nurmaidah Ginting, Putra Nagara, Selly, Ricky Yuwanto, Diana Mariana. Effect of motivation, work environment and workload on employee performance at PT. Benua Penta Global Medan. International Journal of Research and Review. 2021; 8(12): 463-467. DOI: https://doi.org/10.52403/ijrr.20211257 